\title{
From the Desk of the Honorary Secretary General
}

Dear Members,

You will be glad to learn that the institute completed a glorious journey of 50 years on 22nd April 2016 and it was celebrated in a befitting manner. In the morning of 22nd April 2016, members of the institute, which included some very senior former Presidents, Past Vice Presidents and Past Secretaries along with Mr. Chris Smallbone, Past President of the International Institute of Welding and WTIA CEO Emeritus, Dr. Baldev Raj another Past President of IIW and other distinguished guests assembled at IIW India House and hoisted the IIW India Flag. This was a very nostalgic occasion where all present fondly recalled old memories.

The main programme was arranged at Hotel Stadel, Salt Lake, Kolkata, where a day long programme was held and which was attended by around 250 persons including members and guests. The Chief Guest on the occasion was Mr. Sumit Mazumdar, Chairman and Managing Director of TIL Ltd. and immediate Past President of CII (Confederation of Indian Industries). During this momentous occasion, Mr. Chris Smallbone presented a trophy to IIW India President on behalf of the International Institute of Welding and in his speech he complimented and congratulated the institute for completing 50 years.

A symposium on "Welding for Nation Building" was held on this occasion, the objective of which was to take a look at the present status of Welding Technology in India in the key specific areas like Welding Fabrication, Welding Consumables, Welding Power Sources, Control Systems, Automation and Robotics, R\& D of Welding, Modular Welding Education and skilling with the objective of setting directions for Building up a National Welding Capability

During Golden Jubilee Year of the Institute, we have planned to organise various programmes throughout the year as follows :

1) National Quiz Contest on "Metallurgy, Materials and Welding" to be held at the DAE Complex, Kalpakkam, Tamil Nadu on 29th July, 2016.

2) National Welding Meet (NWM-2016) - to be held at College of Engineering, Pune on 27th August, 2016.

3) Young Engineers Contest will be held at Cochin on 12th September, 2016.

4) Young Professional Seminar organised by Baroda Branch on 1st October, 2016 on the theme "Advances in Welding Technology and Automation" at Hotel Crown Plaza, Ahmedabad, Gujarat.

5) Finally, the year ended up with the National Welding Seminar (NWS-2016) to be held at the Science City, Kolkata on 15-17 December, 2016 together with 11th WELD INDIA International Exhibition at Milan Mela Compound, just opposite to Science City, Kolkata.

The 50th Annual General Meeting will be held on 24th of September, 2016 along with the Annual General Assembly of the Institute on 23rd September at Kolkata. All Members are requested to participate whole heartedly in the above programmes.

Best regards,

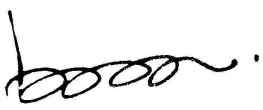

Parimal Biswas

M.No +91 9831052652

E-Mail Id : parimal.biswas@iiwindia.com 